\title{
Pengaruh Penerapan Model Pembelajaran STM (Sains, Teknologi, Masyarakat) Menggunakan Media Peta Konsep Terhadap Minat Belajar
}

\author{
Hayati Nufus $^{1)}$, Yuni Fatisa ${ }^{2 *}$ \\ ${ }^{1}$ Pendidikan Kimia, Tarbiyah dan Keguruan, UIN SUSKA RIAU \\ Email: Hayatinufus49@gmail.com \\ ${ }^{2 *}$ Pendidikan Kimia, Tarbiyah dan Keguruan, UIN SUSKA RIAU \\ Email: Yunifatisa@yahoo.co.id
}

\begin{abstract}
The goal of this study was to find out the effect of the implementation of science, technology, and society (STS) learning model by using concept maps toward students' learning interest in Islamic Senior High School. Therefore, the study was carried out in queasy experiment design and the sample was taken through purposive sampling technique, which consists of two classes, namely $\mathrm{XC}$ as experiment class and $\mathrm{XB}$ as control one. After implementing those learning model and technique, the data was collected through questionnaire and documentation. Due to the statistic analysis, it was examined that the implementation of concept maps technique on experiment class has affected students' interest in learning $81.45 \%$, and it was categorized into good, in contrast, in control group it has affected students' interest about $61.2 \%$ that was categorized into Fair. Similarity, the hypothesis testing by using Mann-Whitney test on the final questionnaire average score has revealed that the $Z_{o}$ (t-obtained) score was -5.74 and $Z_{\text {table }}$ score was -1.96 based on $5 \%$ significant standard, further, when $Z_{\mathrm{o}} \leq-Z_{\text {table, }}$, the null hypothesis was rejected and the alternative hypothesis was accepted. In conclusion, there was the significant effect of science, technology, and society (STS) learning model by using concept maps technique toward students' learning interest in Hydrocarbon class in Islamic Senior High School of Islamic Boarding School Daarun Nahdhah Thawalib Bangkinang for the 2015/2016 academic year.
\end{abstract}

Keywords : Science, Technology, Society (STS) teaching model, concept maps techniques, students' learning Interest, and hydrocarbon.

\section{PENDAHULUAN}

Pendidikan adalah usaha sadar dan terencana untuk mewujudkan suasana belajar dan proses pembelajaran agar peserta didik mampu mengembangkan potensi dirinya untuk memiliki kekuatan spiritual keagamaan, pengendalian diri, kepribadian, kecerdasan, akhlak mulia, serta keterampilan yang diperlukan dirinya, masyarakat, bangsa dan negara [1].

Pentingnya suatu pendidikan telah dijelaskan Allah dalam alqur'an yaitu dalam surat Al-Mujadalah ayat 11:

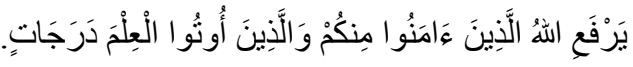

Artinya: "Allah akan meninggikan orangorang yang beriman di antaramu dan orang-orang yang diberi ilmu pengetahuan."(QS.Al-Mujadalah:11)

\footnotetext{
Berdasarkan firman Allah tersebut bahwa orang yang memiliki ilmu pengetahuan akan diangkat derajatnya, artinya tidak sama kedudukan orang yang
}

berilmu dangan yang tidak berilmu. Maka jelaslah bahwa pendidikan itu sangat penting. Pendidikan yang dilaksanakan dalam suatu proses pembelajaran disekolah, dalam penyelenggaraannya tidak selamanya sesuai dengan yang diharapkan dimana ada berbagai masalah yang terjadi dalam proses pembelajaran tersebut. Salah satunya adalah karena dalam proses pembelajaran tidak banyak melibatkan siswa.

Pembelajaran yang melibatkan siswa yang dapat menciptakan suatu keadaan yang menyenangkan bagi siswa dapat meningkatkan pemahaman materi pada siswa. Mata pelajaran yang memerlukan keterlibatan siswa dalam proses pembelajaran salah satunya adalah kimia. Kimia merupakan mata pelajaran yang banyak manfaatnya dalam kehidupan seharihari, sehingga memerlukan keterlibatan siswa dalam proses pembelajaran. Namun dilapangan mempelajari ilmu kimia tidak banyak melibatkan siswa dalam proses pembelajaran, sehingga siswa jarang menyadari manfaat ilmu kimia dalam 
kehidupan sehari - hari dan kurang diminati siswa.

Pada penelitian ini peneliti melakukan observasi dengan membagikan angket berupa lembar pengamatan kepada siswa kelas X di sekolah Madrasah Aliyah Pondok Pesantren Daarun Nahdhah Thawalib Bangkinang. Hasil angket yang telah dibagikan diperoleh bahwa siswa lebih suka bercerita dengan teman sebangkunya ketika guru menjelaskan dan menganggap pelajaran kimia itu sulit sehingga siswa kurang semangat mengikuti pelajaran kimia. Hal ini menunjukkan kurangnya minat siswa pada mata pelajaran kimia. Selain itu siswa lebih tertarik dan semangat dalam menguasai pelajaran agama, karena sekolah tersebut merupakan pesantren maka siswa lebih mendalami ilmu agama. Pelajaran sains, salah satunya kimia kurang diminati siswa.

Minat belajar yang besar cenderung menghasilkan prestasi yang tinggi, sebaliknya minat belajar yang kurang akan mengahsilkan prestasi yang rendah. Menurut Djamarah indikator minat belajar adalah rasa suka/senang, pernyataan lebih menyukai, adanya rasa ketertarikan, adanya keinginan belajar sendiri tanpa disuruh, berpartisipasi dalam aktivitas belajar, memberikan perhatian [2]. Menurut Slameto indikator minat belajar adalah perasaan senang, keterkaitan, penerimaan, keterlibatan [3].

Untuk meningkatkan minat belajar siswa, maka diperlukan cara mengajar yang lebih kreatif sehingga siswa lebih tertarik terhadap mata pelajaran kimia.Telah banyak dikembangkan berbagai model pembelajaran yang dapat digunakan dalam proses belajar mengajar untuk meningkatkan minat belajar siswa. Pada pembelajaran sains dapat digunakan model pembelajaran yang sesuai, karena kimia merupakan pelajaran sains maka salah satu model pembelajaran yang dapat digunakan adalah STM (Sains, Teknologi, Masyarakat). Secara konseptual pendekatan STM dapat dikaitkan dengan asumsi bahwa sains, teknologi, dan masyarakat memiliki keterkaitan timbal balik, saling isi mengisi saling tergantung, saling mempengaruhi dan mendukung dalam mempertemukan antara permintaan dan kebutuhan manusia serta membuat kehidupan masyarakat lebih baik dan mudah. Keterkaitan sains, teknologi dan masyarakat ditunjukkan pada Gambar. 1 [4].

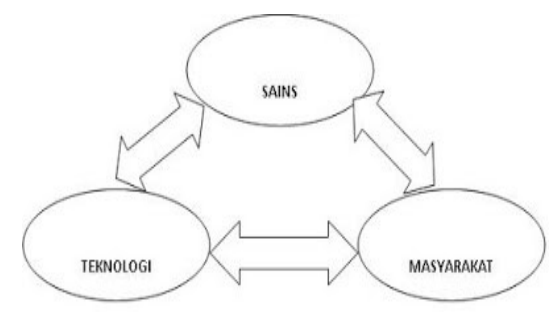

Gambar 1. Interaksi Sains Teknologi Masyarakat

Model pembelajaran STM merupakan salah satu model dalam pembelajaran Sains di sekolah. Sasaran yang ingin dicapai melalui pendekatan STM adalah meningkatkan minat siswa terhadap sains serta membentuk pribadi siswa yang literasi sains dan teknologi. Melalui model pembelajaran STM, para siswa sebagai warga masyarakat diharapkan lebih bertanggung jawab terhadap lingkungan alam dan sosialnya. Model pembelajaran STM merupakan "perekat" yang mempersatukan sains, teknologi, dan masyarakat. Pengajaran Sains akan lebih bermakna jika konsep-konsep, prinsipprinsip, dan teori-teori Sains dikemas dalam kerangka yang bertalian dengan teknologi dan masyarakat [5].

Yager menegaskan model pembelajaran STM dengan landasan kontruktivisme melalui empat fase pembelajaran yaitu: invitasi (invitation), Eksplorasi (exploration), eksplanasi (explanation), dan aksi (action), atau aplikasi (aplikation)[6]

Penelitian Nuryanto mengenai efektifitas pembelajaran pendekatan saling temas (sains, lingkungan, teknologi, masyarakat) mendapatkan hasil bahwa minat belajar siswa pada kelas eksperimen mengalami peningkatan dibandingkan dengan kelas kontrol [7].

Penelitian lain mengenai pengaruh model pembelajaran STM terhadap pemahaman konsep kimia dan sikap ilmiah siswa mendapatkan hasil bahwa terdapat perbedaan pemahaman konsep kimia dan sikap ilmiah siswa dengan model pembelajaran STM dibandingkan dengan pemahan konsep dan sikap ilmiah siswa 
dengan model pembelajaran konvensional[8].

Titik berat pembelajaran sains berwawasan STM adalah mengaitkan antara teknologi dan masyarakat dalam konteks STM. Untuk memudahkan menggunakan model pembelajaran STM dapat digunakan suatu media pembelajaran. Dalam pemilihan media diharapkan sesuai dengan model pembelajaran yang digunakan. Pada penelitian ini digunakan media peta konsep yaitu penuangan ide-ide pikiran sebagai catatan-catatan dalam bentuk grafis sebagai salah satu teknik belajar efektif.

Peta konsep ini dikembangkan oleh Tony Buzean pada 1970-an, yang didasarkan pada kerjanya otak. Otak kita mengingat informasi dalam bentuk gambar, simbol, bentuk-bentuk suara musik dan perasaan. Otak menyimpan informasi dengan pola dan asosiasi seperti pohon dengan cabang dan rantingnya. Peta konsep menggunakan pengingat-ingat visual dan sensorik dalam suatu pola dalam ide-ide yang berkaitan, seperti peta jalan digunakan untuk belajar, mengordinasikan, dan merencanakan.

Peta ini dapat membangkitkan ide-ide rasional dan memicu ingatan dengan mudah, jauh lebih mudah daripada pencatataan tradisional. Oleh karena itu, secara fungsional peta pikiran diartikan sebagai teknik pemanfaatan keseluruhan otak dengan menggunakan citra visual dan prasarana grafis lainnya untuk membentuk kesan. Peta konsep pembelajaran adalah cara dinamik untuk menangkap butir-butir pokok informasi yang signifikan. Teknik tersebut menggunakan format global dan umum yang memungkinkan informasi ditunjukkan dengan cara yang mirip otak berfungsi dalam pelbagai arah yang serempak.

Salah satu materi kimia yang dapat dikembangkan dengan model STM menggunakan media peta konsep adalah materi hidrokarbon, karena pada materi hidrokarbon terdapat banyak konsep yang harus dipahami [9]. Oleh karena itu, peneliti tertarik menggunakkan media peta konsep sebagai media dalam membantu proses pembelajaran menggunakan model pembelajaran STM.
Pada proses pembelajaran, guru dapat mengangkat isu yang berkembang di masyarakat mengenai materi hidrokarbon, karena materi hidrokarbon erat kaitannya dengan kehidupan sehari-hari. Salah satu contohnya adalah Bensin yang digunakan sebagai bahan bakar kendaraan, gas asetilena digunakan sebagai bahan bakar zat pengelas, senyawa etana dan pentana terkandung dalam $L P G$ (Liquefed Natural Gas) yang digunakan sebagai bahan bakar untuk rumah tangga. Beberapa peralatan yang terbuat dari plastik juga merupakan senyawa hidrokarbon yaitu polietilena yang diperoleh melalui reaksi polimerisasi.

Berdasarkan uraian di atas maka tujuan penelitian ini adalah mengetahui pengaruh model pembelajaran STM menggunakan media peta konsep terhadap minat belajar siswa pada materi hidrokarbon.

\section{METODE PENELITIAN}

\section{Jenis Penelitian}

Penelitian ini menggunakan
pendekatan kuantitatif

\section{Waktu dan Tempat Penelitian}

Penelitian ini dilaksanakan pada bulan April hingga pertengahan bulan Mei tahun 2016. Tempat penelitian dilaksanakan di sekolah Madrasah Aliyah Pondok Pesantren Daarun Nahdhah Thawalib Bangkinang.

\section{Target/Subjek Penelitian/Populasi dan Sampel}

Subjek penelitian ini adalah siswa kelas X sekolah Madrasah Aliyah Pondok Pesantren Daarun Nahdhah Thawalib Bangkinang tahun ajaran 2015/2016. Sedangkan objek dalam penelitian ini adalah minat belajar siswa pada mata pelajaran kimia pada pokok bahasan hidrokarbon.

\section{Teknik Pengumpulan Data}

Sampel diambil dengan Teknik purposive sample. Pengumpulan data diambil dengan metode dokumentasi, wawancara dan angket.

Data dianalisis validitas, homogenitas, uji hipotesis dan uji peningktan minat belajar. Analisis uji validitas, peneliti melakukan uji secara isi. Analisis secara isi peneliti melakukan diskusi dengan dosen yaitu Ibu Miterianifa. M.Pd sebagai 
validator 1 dan Ibu Yuni Fatisa M.Si sebagai validator 2 .

Rumus yang digunakan dalam menganalisis data hipotesis adalah uji Mann Witney. [10]

$$
\begin{aligned}
& \mathrm{U}_{1}=\mathrm{n}_{1} \cdot \mathrm{n}_{2}+\frac{\mathrm{n}_{1}\left(\mathrm{n}_{1}+1\right)}{2}-\mathrm{R}_{1} \quad \text { dan } \\
& \mathrm{U}_{2}=\mathrm{n}_{1} \cdot \mathrm{n}_{2}+\frac{\mathrm{n}_{2}\left(\mathrm{n}_{2}+1\right)}{2}-\mathrm{R}_{2}
\end{aligned}
$$

Bila $\mathrm{n}_{1}$ dan $\mathrm{n}_{2}$ lebih dari 20, maka digunakan dengan pendekatan kurva normal rumus $\mathrm{Z}$. Dengan terlebih dahulu menentukan ratarata $U$, dan menentukan simpangan baku.

1) Menentukan rata-rata $U$ dengan rumus:

$$
\mu_{\mathrm{U}}=\frac{1}{2}\left(\mathrm{n}_{1} \cdot \mathrm{n}_{2}\right)
$$

2) Menentukan simpanganbaku (data yang terdapat pengulangan) dengan rumus:

$\delta_{\mathrm{U}}=\sqrt{\left(\frac{\mathrm{n}_{1} \cdot \mathrm{n}_{2}}{\mathrm{~N}(\mathrm{~N}-1)}\right)\left(\frac{\mathrm{N}^{3}-\mathrm{N}}{12}-\sum \mathrm{T}\right)}$

$$
\text { Dengan: }
$$

$\sum \mathrm{T}=\sum \frac{\mathrm{t}^{\mathrm{s}}-\mathrm{t}}{12}$, dimana $\mathrm{t}$ adalah yang berangka sama

3) Menentukan transformasi $Z$ dengan rumus:

$\mathrm{Z}_{\text {hitung }}=\frac{\mathrm{U}-\mu_{\mathrm{U}}}{\delta_{\mathrm{U}}}$

Nilai $Z_{\text {hitung }}$ tersebut kemudian dibandingkan dengan $Z_{\text {tabel }}$ pada taraf signifikan $5 \%$, dengan kriteria tolak $\mathrm{H}_{\mathrm{O}}$ jika:

$Z_{\text {hitung }} \leq-Z_{\text {tabel }}$ atau $Z_{\text {hitung }} \geq Z_{\text {tabel. }}$

Untuk mengetahui tingkat (persentase) minat belajar siswa pada masing-masing kelas eksperimen dan kontrol diperoleh dengan cara sebagai berikut:

1) Menjumlahkan semua skor per butir soal dari tiap-tiap responden.

2) Perolehan data angket dipersentasikan dengan rumus sebagai berikut:

$\mathrm{P}=\frac{F}{N} \times 100 \%$

Keterangan:

$\mathrm{F}=$ Frekuensi yang sedang dicari persentasinya

$\mathrm{N}=$ skor maksimal

$\mathrm{P}=$ Angka persentase

Untuk mengetahui tingkat kriteria tersebut, selanjutnya skor yang diperoleh (dalam \%) dengan analisis deskriptif persentase dikonsultasikan dengan tabel kriteri [11]
Teknik korelasi product moment merupakan salah satu teknik untuk mencari tingkat keeratan hubungan antara dua variabel dengan cara memperkalikan monen-monen (hal-hal penting) kedua variabel tersebut.

Dengan rumus:

$$
r_{x y}=\frac{N \sum X Y-\left(\sum X\right)\left(\sum Y\right)}{\sqrt{\left[N \sum X^{2}-\left(\sum X\right)^{2}\right]\left[N \sum Y^{2}-\left(\sum Y\right)^{2}\right]}}
$$

$$
\begin{aligned}
& \text { keterangan: } \\
& \mathrm{N}=\text { Sampel } \\
& \mathrm{X}=\text { Variabel 1 } \\
& \mathrm{Y}=\text { Variabel } 2
\end{aligned}
$$

\section{HASIL DAN PEMBAHASAN}

\section{Validitas Instrumen}

TABEL 1. Hasil Pengolahan Angket Validator Pertama

\begin{tabular}{llcc}
\hline Indikator & $\begin{array}{c}\text { No } \\
\text { Soal }\end{array}$ & $\begin{array}{c}\text { Rata- } \\
\text { rata }\end{array}$ & Keterangan \\
\hline Pertama & 1,2, & 75 & Baik \\
& 3 & & \\
Kedua & 4,5, & 75 & Baik \\
& 6,7 & & \\
Ketiga & 8,9, & 75 & Baik \\
& 10, & & \\
& 11 & & \\
Kempat & 12, & 75 & Baik \\
& 13, & & \\
& 14, & & \\
& 15, & & \\
& 16, & & \\
& 17, & & \\
& 18, & & \\
& 19 & & \\
Kelima & 20, & 75 & Baik \\
& 21, & & \\
& 22, & & \\
& 23, & & \\
& 24, & & \\
& 25 & & \\
\hline
\end{tabular}

Selanjutnya hasil validitas secara isi validator ke 2 dapat dilihat pada tabel IV.2 
TABEL.2 Hasil Pengolahan Angket Validator Kedua

\begin{tabular}{llll}
\hline Indikator & $\begin{array}{c}\text { No } \\
\text { Soal }\end{array}$ & $\begin{array}{c}\text { Rata- } \\
\text { rata }\end{array}$ & Keterangan \\
\hline Pertama & 1,2, & 87,5 & Baik \\
& 3 & & \\
Kedua & 4,5, & 81,25 & Baik \\
& 6,7 & & \\
Ketiga & 8,9, & 85,93 & Baik \\
& 10, & & \\
& 11 & & \\
Kempat & 12, & 80,46 & Baik \\
& 13, & & \\
& 14, & & \\
& 15, & & \\
& 16, & & \\
& 17, & & \\
& 18, & & \\
& 19 & & \\
Kelima & 20, & 89,58 & Baik \\
& 21, & & \\
& 22, & & \\
& 23, & & \\
& 24, & & \\
& 25 & & \\
\hline
\end{tabular}

Penjelasan mengenai tabel IV.12 dapat dilihat pada lampiran E. Dari pengolahan data di dapat bahwa nilai $X_{\text {hitung }}^{2}=0,345$ dan nilai $X_{\text {tabel }}^{2}$ untuk $\alpha=$ 0,05 dengan $V_{1}(30), \quad V_{2}(34), V_{3}$ (34) adalah $\mathrm{dk}=$ Kelas $-1=3-1=2$, jadi nilai $X_{\text {tabel }}^{2}$ adalah 5,99. Jadi, $X_{\text {hitung }}^{2}(0,345)<$ $X_{\text {tabel }}^{2}(5,99)$, artinya kemampuan populasi dari tiga kelas tersebut berkemampuan homogen.

\section{Uji Hipotesis}

Uji hipotesis yang digunakan pada penelitian ini adalah uji Man Whitney. Uji ini merupakan test yang terbaik untuk menguji hipotesis komparatif dua sampel independen bila datanya berbentuk ordinal. Bila $\mathrm{n}_{1}{ }^{+} \mathrm{n}_{2}$ lebih dari 20 maka langkah selanjutnya mencari kurva normal rumus $Z$ Pada penelitian ini sampel yang digunakan berjumlah 34 untuk kelas eksperimen dan 34 untuk kelas kontrol. Karena sampel lebih besar dari 20 maka setelah dihitung menggunakan uji Mann Whitney langkah selanjutnya adalah mencari pendekatan kurva normal rumus $\mathrm{Z}$.

Hasil perhitungan $U_{1}$ adalah 1071 dan $U_{2}$ adalah 113,45 , nilai $U$ yang digunakan pada rumus $\mathrm{Z}$ adalah nilai $\mathrm{U}$ terendah. Pada analisis hipotesis telah dijelaskan bahwa hasil perhitungan nilai $Z_{\text {hitung }}(-5,74)$ lebih kecil dari nilai $-Z_{\text {tabel }}(-$ $1,96)$. Maka hipotesis yang diterima adalah hipotesis $\mathrm{H}_{\mathrm{a}}$.

\section{Analisis Minat Belajar}

Analisis minat belajar siswa diukur menggunakan lima indikator minat yaitu :

\section{Indikator Pertama ( Perasaan senang)}

Hasil angket akhir kelas eksperimen untuk indikator pertama adalah $83,32 \%$ dengan kriteria baik sedangkan kelas kontrol $66,2 \%$ dengan kriteria cukup. Ternyata perasaan senang atau menyukai kimia pada kelas eksperimen lebih baik dari pada kelas kontrol. Hal ini terlihat ketika peneliti mengajar pada pertemuan kedua bahwa kelas eksperimen tidak ada yang keluar masuk kelas ketika proses belajar mengajar berlangsung dan siswa lebih semangat dalam belajar.

\section{Indikator Kedua ( Ketertarikan)}

Selanjutnya untuk indikator kedua yaitu ketertarikan, hasil angket akhir diperoleh untuk kelas eksperimen $81,02 \%$ dengan kriteria baik sedangkan kelas kontrol $62,55 \%$ dengan kriteria cukup. Ketertarikan siswa pada kelas eksperimen terlihat pada pertemuan kedua dan ketiga, bahwa siswa mau bertanya kepada guru tentang materi kimia yang tidak dipahami. Sedangkan kelas kontrol lebih banyak diam dan mendengarkan.

\section{3) Indikator Ketiga ( Perhatian)}

Pada indikator ketiga untuk hasil angket akhir pada kelas eksperimen diperoleh $81,42 \%$ dengan kriteria baik dan kelas kontrol 61,6\% dengan kriteria cukup.

Pada pertemuan pertama sampai ke empat pada kelas eksperimen siswa mampu fokus memperhatikan guru, disini terlihat keinginan untuk paham pada materi hidrokarbon. Sedangkan 
kelas kontrol masih ada siswa yang suka bercanda dengan teman ketika guru menjekaskan.

\begin{tabular}{ccc}
\hline & $\begin{array}{c}\text { Kelas } \\
\text { Eksperimen }\end{array}$ & $\begin{array}{c}\text { Kelas } \\
\text { Kontrol }\end{array}$ \\
\hline Sebelum & $58,20 \%$ & $50,14 \%$ \\
Setelah & $81,46 \%$ & $63,34 \%$ \\
\hline
\end{tabular}

\section{4) Indikator Keempat ( Partisipasi Aktivitas Belajar)}

Hasil angket akhir pada indikator keempat untuk kelas eksperimen adalah $74,82 \%$ dengan kriteria baik. Sedangkan kelas kontrol diperoleh sebesar $61,30 \%$ dengan kriteria cukup. Hal ini terlihat pada pertemuan kedua siswa kelas eksperimen saat mngerjakan kuis mereka tenang dan santai. Begitu juga ketika proses pembelajaran pada pertemuan keempat siswa mau maju kedapan kelas megerjakan latihan tanpa harus ditunjuk guru. Artinya siswa mau maju dengan suka rela. Berbeda dengan kelas kontrol saat kuis siswa masih ada yang menyontek, bahkan untuk mengerjakan latihan kedepan kelas siswa malu-malu. Ketika ditunjuk guru baru siswa mau mngerjakan kedepan kelas.

\section{5) Indiaktor Kelima ( Keinginan Belajar sendiri)}

Pada indikator kelima hasil kelas eksperimen diperoleh sebesar 86,74\% dengan kriteria baik. Sedangkan untuk kelas kontrol diperoleh 56,62\% dengan kriteria cukup. Pada indikator kelima terlihat perbedaan antara kelas kontrol dan eksperimen, yaitu untuk pertemuan ketiga dan keempat kelas eksperimen belajar kimia diluar jam kimia. Artinya mereka belajar di jam tambahan. Siswa pada kelas eksperimen tidak mengeluh bahkan semangat untuk belajar kimia diluar jam kimia. Sedangkan kelas kontrol hanya sekali belajar diluar jam kimia yaitu hanya dipertemuan ketiga. Karena banyak siswa yang beralasan tidak bisa keluar rumah. Artinya mereka menolak untuk belajar kimia diluar jam pelajaran kimia.
Analisis minat belajar pada penelitian ini diperoleh dari hasil skor angket sebelum penelitian (awal) dan nilai angket setelah penelitian (akhir). Angket diberikan kepada kelas eksperimen dan kontrol, sebelum dan setelah penelitian.Pada penelitian ini soal angket yang digunakan adalah 25 soal, skor totalnya adalah 100. Hasil angket untuk kelas eksperimen dan kontrol dapat dilihat pada Tabel. 4 dan Gambar. 2.

Gambar 2. Grafik Hasil Keseluruhan Indikator Persentase minat

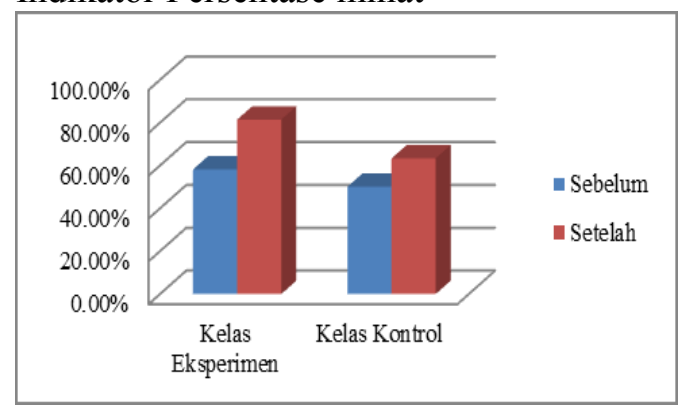

Penerapan model STM dengan media peta konsep pada penelitian ini diharapkan memberikan dampak positif diantaranya, ada keinginan belajar kimia tanpa merasa terpaksa, dan menyadari pentingnya ilmu kimia dalam kehidupan sehari-hari. Terlihat dari hasil angket akhir untuk kelas eksperimen dan kontrol memiliki perbedaan. Untuk kelas eksperimen memperoleh hasil persentase angket akhir dari indikator pertama sampai kelima sebesar 81,46\% dengan kriteria baik, sedangkan kelas kontrol hanya memperoleh sebsesar $61,26 \%$ dengan kriteria cukup.

Adapun sebelum penelitian hasil keseluruhan persentase minat untuk kelas eksperimen memperoleh hasil sebesar $58,20 \%$ dengan kriteria cukup, begitu juga dengan kelas kontrol memperoleh hasil sebesar $50,14 \%$ dengan kriteria cukup. Artinya kelas eksperimen mengalami peningkatan minat belajar dari cukup menjadi baik.

Begitu juga penelitian yang dilakukan oleh Sari, hasil penelitiannya menunjukkan terdapat perbedaan aktivitas dan hasil balajar siswa yang diajar menggunakan model pembelajaran STM dengan yang diajar tanpa model pembelajaran STM pada materi pemisahan campuran dengan pengaruh 
model pembelajaran STM sebesar 21,57\% [12]

\section{Uji Korelasi Product Momoent}

Setela dilakukan penelitian, yaitu menerapkan model Pembelajaran STM menggunakan media peta konsep terhadap minat belajar siswa. Maka diakhir pembelajaran dilakukan evaluasi. Tujuan dilakukan evaluasi adalah untuk membandingkan nilai evaluasi dengan hasil angket akhir pada kelas kontrol dan eksperimen. Rumus yang digunakan untuk membandingkan hasil evaluasi dan hasil angket akhir adalah uji Pearson product moment. Hasil perhitungan dapat dilihat pada tabel 5

Tabel. 5 Hasil Pengolahan Uji Korelasi

\begin{tabular}{llll}
\hline Kelas & $\mathbf{r}_{\text {hitung }}$ & $\mathbf{r}_{\text {tabel }}$ & Hasil \\
\hline Eksperimen & 0,362 & 0.349 & $\begin{array}{l}\text { Ada } \\
\text { korelasi }\end{array}$ \\
Kontrol & 0,384 & 0,349 & $\begin{array}{l}\text { Ada } \\
\text { korelasi }\end{array}$ \\
\hline
\end{tabular}

Setelah data minat dan hasil evaluasi dikorelasikan, maka didapat untuk kelas eksperimen dan kontrol ternyata minat dan hasil evaluasi memiliki korelasi pada taraf $5 \%$.

\section{SIMPULAN}

Berdasarkan hasil penelitian, dapat diambil simpulan sebagai berikut yaitu:

Ada pengaruh model pembelajaran STM (Sains Teknologi Masyarakat) Menggunakan media peta konsep terhadap minat belajar siswa kela $\mathrm{X}$ Pondok Pesantren Daarun Nahdha Bangkinang.

Hasil keseluruhan perhitungan persentase minat belajar setelah penerapan model pembelajaran STM (Sains Teknologi Masyarakat) menggunakan media peta konsep untuk kelas eksperimen adalah $81,46 \%$ dengan kriteria baik dan kelas kontrol sebesar $61,26 \%$ dengan kriteria cukup.

\section{REFERENSI}

[1].M. Syah, "Psikologi belajar", Jakarta: Rajawali pres, 2012.

[2].B. Djamarah, "Psikologi Belajar". Jakarta: PT Rineka Cipta, 2008.

[3].Slameto, "Belajar Dan Faktor-Faktor Yang Mempengaruhi”. Jakarta: Rineka Cipta, 2010.

[4].A.Poedjiadi, "Sain Teknologi Masyarakat, Model Pembelajaran Konstekstual Bermuatan Nilai”. Bandung: PT Remaja Rosdakarya, 2005.

[5].F. Zuh dan K. Prasetyo, "Pembelajaran Sains", Yogyakarta: Ombak, 2014.

[6].Elangbiru, "Model Pembelajaran STM ( Sain Teknologi Masyarakat)", Diakses tanggal 27 januari dari http/blogspot.com, 2016.

[7].Nuryanto, "Efektifitas Pembelajaran Kimia Dengan Pendekatan Salingtemas Ditinjau Dari Minat Dan Hasil Belajar Siswa", universitas negeri semarang, 2010.

[8].I.Made,"Pengaruh Model Pembelajaran STM (Sains, Teknologi, Masyarakat) Terhadap Pemahaman Konsep kimia Dan Sikap Ilmiah Siswa”, Universitas Pendidikan Ganesha, 2012.

[9].N. Suryani, Leo Agung, Strategi Belajar Mengajar, Yogyakarta: ombak 2012

[10].Sugiyono, "Statistik non parametrics" Bandung: Alfabeta, 2015

[11].A.Jihad, dan A. Haris, "Evaluasi Pembelajaran" . Yogyakarta Multi Pressindo, 2011.

[12].S. U. Pianita, "Pengaruh Model Pembelajaran STM Terhadap 
Aktifitas dan Hasil Belajar Siswa

SMP", Journal of Chemistry

Education, vol. 26, pp. 14-17, 2014. 